\title{
Chemical fractionation of carbohydrate and protein composition of corn silages fertilized with increasing doses of nitrogen
}

\author{
Mikael Neumann ${ }^{1}$ José Laerte Nörnberg ${ }^{2}$ Guilherme Fernando Mattos Leão ${ }^{3}$ \\ Egon Henrique Horst ${ }^{4}$ Danúbia Nogueira Figueira ${ }^{5}$
}

1Departamento de Medicina Veterinária, Universidade Estadual do Centro-Oeste (UNICENTRO), Rua Simeão Camargo Varela de Sá, 03, Vila
Carli, 85040-080, Guarapuava, PR, Brasil. E-mail: neumann.mikael@hotmail.com. "Corresponding author.
2Departamento de Zootecnia, Universidade Federal de Santa Maria (UFSM), Santa Maria, RS, Brasil.
${ }^{3}$ Departamento de Zootecnia, Universidade Federal do Paraná (UFPR), Curitiba, PR, Brasil.
${ }^{4}$ Departamento de Ciência Animal, Universidade Estadual de Londrina (UEL), Londrina, PR, Brasil.
${ }^{5}$ Departamento de Zootecnia, Universidade Estadual Paulista “Júlio de Mesquita Filho" (UNESP), Jaboticabal, SP, Brasil.

ABSTRACT: The use of nitrogen fertilizers in corn crops for silage can improve both production and, theoretically, nutritional quality, especially carbohydrate and protein fractions, thereby optimizing animal production. Thus, the aim of this study was to evaluate the effect of increasing levels of nitrogen fertilization in carbohydrate and protein fractionation on the resulting corn silage (Zea mays L.). Nitrogen fertilization was carried out in the urea form (45-00-00) in V5 stage, at the following doses: $T_{1}: 0 \mathrm{~kg} \mathrm{~N} \mathrm{ha-1} ; T_{2}: 45 \mathrm{~kg} \mathrm{~N} \mathrm{ha}^{-1} ; T_{3}: 90 \mathrm{~kg} \mathrm{~N} \mathrm{ha} a^{-1}$; and $T_{4}: 135 \mathrm{~kg} \mathrm{~N} \mathrm{ha-1}$. Crops were harvested at R4 stage and submitted to ensiling in experimental PVC silos. The chemical composition of the resulting silage was evaluated after silo opening. There was no statistical difference $(P<0.05)$ in the average contents of gross protein $(G P)$, as well as its $C$ fraction, showing that increasing nitrogen doses in coverage linearly increased GP and linearly decreased its $C$ fraction. For total carbohydrates, there was a linear decreasing behavior due to such consumption with the highest levels of nitrogen applied. Increased nitrogen fertilization dose in corn also linearly enhanced $\mathrm{pH}$ in the resulting silage. Therefore, nitrogen increases in coverage can alter carbohydrates and GP fractionation of corn silage, with increases in soluble fiber, GP, and $\mathrm{pH}$, and reduction in the protein indigestible fraction. Key words: starch, organic acids, C fraction, $p H$, solubility.

Composição química fracional de carboidratos e de proteínas de silagens de milho fertilizadas com doses crescentes de nitrogênio

RESUMO: $O$ uso de adubação nitrogenada em lavouras de milho visando produção de silagem pode manipular tanto a produção, quanto teoricamente melhorar a qualidade nutricional, em especial as frações de carboidratos e proteinas, otimizando a produção animal. Desta forma, o objetivo do trabalho foi avaliar o efeito de niveis crescentes de adubação nitrogenada em cobertura sobre o fracionamento de carboidratos e proteínas na silagem de milho (Zea mays L.) resultante. A adubação nitrogenada em cobertura foi realizada em estádio V5, sob a forma uréia (45-00-00), nas seguintes doses: $T_{1}: 0 \mathrm{~kg}$ de $N \mathrm{ha}^{-1} ; T_{2}: 45 \mathrm{~kg}$ de $\mathrm{N} \mathrm{ha}^{-1} ; T_{3}: 90 \mathrm{~kg}$ de $\mathrm{N} \mathrm{ha} \mathrm{a}^{-1} ; T_{4} 135 \mathrm{~kg}$ de $\mathrm{N} \mathrm{ha}{ }^{-1}$. Após a colheita do material em estádioR4, foi realizada a confecção da silagem em silos experimentais de PVC, e após a abertura dos mesmos avaliou-se a composição química da silagem. Houve diferença estatística $(P<0,05)$ para os teores médios de proteína bruta $(P B)$, assim como de sua fração $C$, evidenciando que o aumento da dose de nitrogênio em cobertura aumentou linearmente a PB e diminuiu linearmente a sua fração $C$. Para os carboidratos totais também houve um comportamento linear decrescente em reflexo do consumo destes em detrimento as maiores doses de nitrogênio aplicadas. $O$ aumento da dose de adubação nitrogenada em cobertura à cultura do milho também gerou um incremento nos valores de pH na silagem resultante com comportamento linear. É perceptível que o aumento de doses de nitrogênio em cobertura pode alterar o fracionamento de carboidratos e PB da silagem de milho, sendo que há aumento da participação de fibra solúvel, PB e o pH e redução da fração indigestivel da proteína. Palavras chave: amido, ácidos orgânicos, fração $\mathrm{C}$, $\mathrm{pH}$, solubilidade.

\section{INTRODUCTION}

Silage nutritional quality is closely related to the fertilizer support offered to the crop, since the nutrient content the plant extracts from the soil during its cycle will influence not only productively but also directly the bromatological composition of the plant and the resulting silage (MALAVOLTA et al., 1997). Therefore, it is necessary to ensure a nutrient supply to replace the quantity extracted by the plant to maximize productivity, especially in crops for whole plant corn silage production, which generates nutrient exportation without soil recomposition and that could cause its rapid impoverishment (UENO et al., 2011).

Among all nutrients, nitrogen is the most frequently exported, from the soil to the plant, in silage production (NEUMANN et al., 2005); however, approximately $75 \%$ of this nitrogen is transferred directly to grains. In addition, nitrogen has a great relevance in plant health and productivity as it is a nutrient active in several metabolic routes, participating in the synthesis of protein, nucleic 
acids, membranes, hormones, and other cellular constituents (TAIZ \& ZEIGER, 2002).

In another perspective, ingested nitrogen has several functions in animals, the most common of which is amino acid synthesis. This ingested nitrogen may be in the form of proteins or peptides, or also in its free form (non-protein nitrogen); based on that, the degradation of these compounds in the ruminal environment is modulated, being subdivided into fractions according to its degradation rate (NRC, 1996).

In addition, proteolysis and fixation of these compounds by ruminal microorganisms is energy dependent; thus, higher nitrogen concentrations may imply higher energy expenditure-a fact that leads to alteration of carbohydrate fractions (SNIFFEN et al., 1992). Therefore, there must be an ideal balance between carbohydrates and protein fractions in the diet of these animals.

Fractionation of these nutrients is essential for nutrition of precision ruminants. Through this fractionation, it is possible to promote dietary changes aiming to generate greater nutrient utilization and synchronism, inducing better rumen health, longevity, reduction of reproductive problems, and reduced environmental pollution by reducing excretion of nutrients, such as nitrogen (CNCPS, 2002).

Thus, the objective of this study was to evaluate the effect of increasing levels of nitrogen fertilization on the chemical composition of carbohydrates and proteins in the resulting corn silage (Zea mays L.).

\section{MATERIALS AND METHODS}

This study was conducted in the Animal Production Center (Nupran, Núcleo de Produção Animal) from the Department of Agrarian and Environmental Sciences of Universidade Estadual do Centro-Oeste (Unicentro), located in the city of Guarapuava, state of Paraná, Brazil. The soil of the study area is classified as typical haplohumox (POTT et al., 2007), and presented the following chemical characteristics on its 0 to $20 \mathrm{~cm}$ profile, before planting: $\mathrm{pH} \mathrm{CaCl}_{2} 0.01 \mathrm{M}: 4.7$; $\mathrm{P}: 1.1 \mathrm{mg} \mathrm{dm}^{3}$; $\mathrm{K}^{+}: 0.2 \mathrm{cmol}_{\mathrm{c}} \mathrm{dm}^{-3}$; Mo: $2.62 \% ; \mathrm{Al}^{3+}: 0.0 \mathrm{cmol}_{\mathrm{c}} \mathrm{dm}^{-3}$; $\mathrm{H}^{+}+\mathrm{Al}^{3+}: 5.2 \mathrm{cmol}_{\mathrm{c}} \mathrm{dm}^{-3} ; \mathrm{Ca}^{2+} 5.0 \mathrm{cmol}_{\mathrm{c}} \mathrm{dm}^{3} ; \mathrm{Mg}^{2+}$ : $5.0 \mathrm{cmol}_{\mathrm{c}} \mathrm{dm}^{-3}$ and base saturation: $67.3 \%$.

The corn crop (Zea mays L.) was created on November $4^{\text {th }}$ through direct planting system. The experimental material was hybrid Dow 766, in early cycle, planted observing $80 \mathrm{~cm}$ spacing, sowing depth of
$4 \mathrm{~cm}$, and density of five plants per linear meter, according to the recommendations from the breeding company. Corn planting was performed in plots of total area of $28.8 \mathrm{~m}^{2}(4.8 \mathrm{~m} \times 6.0 \mathrm{~m})$, from which $16 \mathrm{~m}^{2}(3.2 \mathrm{~m} \times 5.0 \mathrm{~m})$ in the central area was used for analysis. Base fertilization consisted of $350 \mathrm{~kg}$ ha ${ }^{1}$ of $08-30-20\left(\mathrm{~N}_{-} \mathrm{P}_{2} \mathrm{O}_{5}-\mathrm{K}_{2} \mathrm{O}\right)$ formulation, according to the Fertilization and Liming Guidelines for the states of Rio Grande do Sul and Santa Catarina (2004). Phytosanitary management was conducted through crop technical reports. Thirtyfive days after planting, in V5 crop development stage, cover fertilization was applied in the form of urea (4500-00) in different dosage according to the following treatments: $\mathrm{T}_{1:} 0 \mathrm{~kg} \mathrm{~N} \mathrm{ha}^{-1} ; \mathrm{T}_{2:} 45 \mathrm{~kg} \mathrm{~N} \mathrm{ha}^{-1} ; \mathrm{T}_{3:} 90 \mathrm{~kg} \mathrm{~N} \mathrm{ha}^{-1}$; and $\mathrm{T}_{4} 135 \mathrm{~kg} \mathrm{~N} \mathrm{ha}^{-1}$. These fertilization dosages were based on those used by local farmers.

Corn plants were harvested close to its physiological maturation, in chalky grain cob formation stage (R4), according to the classification proposed by RITCHIE et al. (2003). Plants of each plot were harvested $20 \mathrm{~cm}$ from the soil surface, chopped in stationary forage equipment and ensiled in laboratory silos of PVC tubes of $10 \mathrm{~cm}$ diameter and $50 \mathrm{~cm}$ length. The material was manually compacted and properly identified. Silos were stored in a covered area for 30 days and, after opening, a 500g sample of each treatment was collected, weighed and pre-dried in forced air oven at $55^{\circ} \mathrm{C}$ until constant weight, to determine the content of dry matter (DM), according to AOAC (1995). Then the samples were milled in a "Wiley" type mill, using a $1 \mathrm{~mm}$ sieve mesh.

The total dry matter (TDM) was determined in an oven at $105^{\circ} \mathrm{C}$; gross protein (GP) was determined by micro Kjeldahl method; and mineral matter (MM) and ethereal extract (EE) were determined according to AOAC (1995). Also, neutral detergent fiber (NDF) levels were determined using thermostable $\alpha$-amylase (Termamyl 120L, Novozymes Latin America Ltda.) according to Van SOEST et al. (1991); and acid detergent fiber (ADF) content was determined according to Goering \& Van SOEST (1970). Levels of neutral detergent insoluble nitrogen (NDIN) and acid detergent insoluble nitrogen (ADIN) and GP fractions were calculated according to LICITRA et al. (1996).

NDF was subsequently corrected for ashes and proteins (NDFap) by discounting the remaining protein in NDF, which was determined after multiplying the factor of 6.25 by NDIN content and the residual ash. Non-fibrous carbohydrates corrected 
for ashes and proteins (NFCap) were obtained through the equation proposed by SNIFFEN et al. (1992): NFCap = 100 - (NDFap + EE + GP + MM).

The $\mathrm{pH}$ readings were performed using a digital $\mathrm{pH}$ meter, according to the methodology developed by CHERNEY \& CHERNEY (2003). Ammoniac nitrogen determination $\left(\mathrm{NH}_{3} \mathrm{NT}^{-1}\right)$ was based on BOLSEN et al. (1992). Soluble sugar content (SS) was determined according to HALL (2000); and organic acids according to SILVA \& QUEIRÓZ (2009). Starch content was determined according to the methodology described by WALTER et al. (2005). The soluble fiber (SF) contents were determined through the methodology proposed by AOAC (1995). Total digestible nutrient contents (NDT) were obtained from the equation of BOLSEN et al. (1992).

This study had a randomized block design, consisting of four treatments with three replicates each. Data collected for each parameter were submitted to analysis of variance to compare averages at a significance level of $5 \%$ by Tukey test, and also to polynomial regression analysis using the "proc reg" procedure, processed in SAS statistical software (1993).

\section{RESULTS AND DISCUSSION}

Table 1 presents the average GP content, as well as its fractions according to the different levels of nitrogen fertilization. A significant difference was observed between the treatments in both GP content and $\mathrm{C}$ fraction. In GP, $135 \mathrm{~kg} \mathrm{~N}^{-1}$ fertilization was associated with the highest content $(8.60 \%)$ between treatments. In contrast, the highest $\mathrm{C}$ fraction value was observed in the treatment without nitrogen cover fertilization $(10.21 \%)$.

MENGEL (2001) states that nitrogen increases in cover fertilization generates increases in plant GP content and, consequently, increases in silage, as this nutrient accounts for approximately $16 \%$ of the constitution of these molecules. Figure 1 shows the contrasting GP and $\mathrm{C}$ fraction behavior, with GP showing an increasing linear behavior, incrementing its content by $0.0085 \%$ for each $\mathrm{kg}$ of nitrogen applied, and fraction $\mathrm{C}$ showing the opposite behavior, linearly decreasing by $0.0087 \%$ for each increase in $\mathrm{kg}$ of nitrogen applied. Increasing nitrogen dose in cover fertilization provided an increase in protein value and; in contrast, decreased the indigestible

Table 1 - Average levels of gross protein and total carbohydrates (\% in DM) and its fractions ( $\%$ of GP and $\%$ of TC) in corn silage grown with different cover nitrogen fertilizer treatments.

\begin{tabular}{|c|c|c|c|c|c|c|c|}
\hline \multirow{2}{*}{\multicolumn{2}{|c|}{ 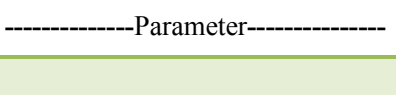 }} & \multicolumn{4}{|c|}{ N levels in cover fertilization $\left(\mathrm{kg} \mathrm{ha}^{-1}\right)$} & \multirow[t]{2}{*}{ Average } & \multirow[t]{2}{*}{ Coefficient of Variation } \\
\hline & & 1 & 45 & 90 & 135 & & \\
\hline \multicolumn{2}{|l|}{ GP } & $6.05^{\mathrm{D}}$ & $7.00^{\mathrm{C}}$ & $7.72^{\mathrm{B}}$ & $8.60^{\mathrm{A}}$ & 7.34 & 3.81 \\
\hline \multicolumn{2}{|l|}{-} & 49.36 & 48.77 & 51.92 & 53.55 & 50.90 & 10.38 \\
\hline \multicolumn{2}{|l|}{ B1 } & 7.01 & 7.69 & 6.06 & 5.12 & 6.47 & 40.53 \\
\hline \multicolumn{2}{|l|}{ B2 } & 28.81 & 28.11 & 27.78 & 27.81 & 28.13 & 16.84 \\
\hline \multicolumn{2}{|l|}{ B3 } & 4.59 & 5.86 & 4.76 & 5.91 & 5.39 & 40.42 \\
\hline \multicolumn{2}{|l|}{$\mathrm{C}$} & $10.21^{\mathrm{A}}$ & $9.55^{\mathrm{A}}$ & $9.46^{\mathrm{A}}$ & $7.60^{\mathrm{B}}$ & 9.21 & 8.08 \\
\hline--- & $\mathrm{TC}$ & $90.22^{\mathrm{A}}$ & $89.46^{\mathrm{AB}}$ & $\begin{array}{l}\text { In MS---- } \\
88.37^{\mathrm{BC}}\end{array}$ & $87.99^{\mathrm{C}}$ & 89.01 & 1.09 \\
\hline \multirow[t]{2}{*}{ Fraction A } & Soluble sugars & 2.83 & 2.39 & $\begin{array}{c}\text { of CT--- } \\
3.12\end{array}$ & 3.94 & 3.07 & 28.93 \\
\hline & Organic acids & $10.12^{\mathrm{AB}}$ & $11.75^{\mathrm{A}}$ & $9.80^{\mathrm{AB}}$ & $7.18^{\mathrm{B}}$ & 9.71 & 15.18 \\
\hline \multirow[t]{2}{*}{ Fraction B1 } & Soluble fiber & $9.70^{\mathrm{C}}$ & $10.55^{\mathrm{BC}}$ & $11.97^{\mathrm{B}}$ & $14.49^{\mathrm{A}}$ & 11.68 & 10.05 \\
\hline & Starch & $28.36^{\mathrm{A}}$ & $27.07^{\mathrm{AB}}$ & $26.06^{\mathrm{AB}}$ & $24.43^{\mathrm{B}}$ & 26.48 & 8.92 \\
\hline \multirow[t]{2}{*}{ Fraction B2 } & Hemicellulose & 20.77 & 19.72 & 20.89 & 21.72 & 20.78 & 9.07 \\
\hline & Cellulose & 24.65 & 24.65 & 24.33 & 24.32 & 24.49 & 8.72 \\
\hline Fraction C & Lignin & 3.57 & 3.86 & 3.84 & 3.91 & 3.80 & 18.92 \\
\hline
\end{tabular}

Averages followed by different letters in the line differ $(\mathrm{P}<0.05)$ from each other by the Tukey test. 


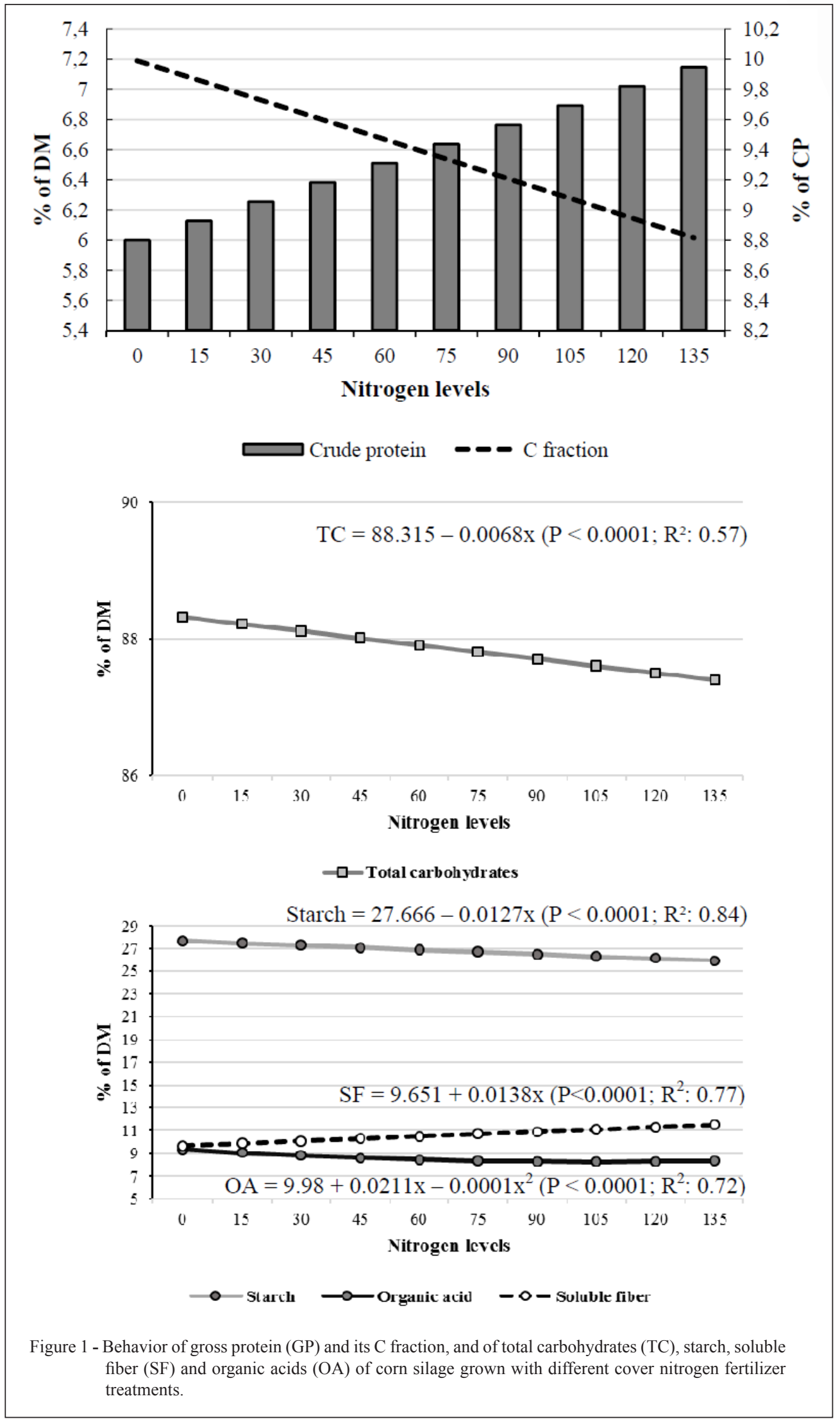

Ciência Rural, v.47, n.5, 2017. 
fractions. It occurs when higher cover nitrogen doses exceed the plant energetic ability for protein synthesis and formation of true protein (TAIZ \& ZEIGER, 2002). This process also depends on insolation, temperature, precipitation, and air relative humidity conditions. NNP is an integral part of A fraction, or also considered as readily digestible by ruminants (CNCPS, 2002).

A significant statistical difference $(\mathrm{P}<0.05)$ was observed in average carbohydrates, organic acids (part of A fraction) and starch (part of B1 fraction) values between treatments. However, there was no statistically significant difference $(\mathrm{P}>0.05)$ for non-fibrous carbohydrates corrected for ash and protein, soluble fiber (fraction B1), hemicellulose and cellulose (fraction B2), neither for $\mathrm{C}$ fraction.

According to Van SOEST (1994), total carbohydrates are relevant, since they represent the main energy source for microbial fermentation, being converted into shortchain fatty acids. Between the treatments, the highest content was observed in silage without nitrogen fertilization $(88.05 \%)$ and the lowest in silage of $135 \mathrm{~kg} \mathrm{~N} \mathrm{ha}^{-1}$ treatment $(86.11 \%)$, representing a $2.20 \%$ reduction. Generally, it implied a decreasing linear behavior of 0.0068 for each increase in $\mathrm{kg}$ of nitrogen per hectare (Figure 1). These findings may be justified by the fact that there was a greater consumption of these carbohydrates to turn the increased amount of available nitrogen into protein, which tends to be a natural response of the plant (TAIZ \& ZEIGER, 2002).

This mechanism also has implications for starch, since its highest value was observed without nitrogen fertilization $(25.59 \%)$, with a decrease of $0.0127 \mathrm{~kg}$ for each $\mathrm{kg}$ of nitrogen applied. Regarding the organic acids, the highest value was observed in the treatment with $45 \mathrm{~kg} \mathrm{~N}^{-1}$ (11.41\%).

Soluble fibers linearly increased by 0.0138 for each $\mathrm{kg}$ of nitrogen applied. In other words, more fertilized silages had increased amounts of soluble fiber, which is the fraction of greatest potential for digestibility. The same was reported by MASOERO et al. (2011), who analyzed different levels of reduced nitrogen fertilizer in corn crops (without nitrogen fertilization, 100 and $150 \mathrm{~kg} \mathrm{~N} \mathrm{ha}^{-1}$ ) and observed increased fiber digestibility in corn silage, especially in leaf and inferior stalk areas.

However, e increase in nitrogen fertilization did not influence the nutritional parameters, as indicated in table 2. Even with decreased starch concentration, as mentioned above, the content of total digestible nutrients did not change with increasing nitrogen fertilization. These results demonstrate the recommendations of other authors for high quality silage production (BASSEGIO et al., 2015); i.e., the selection of hybrids presenting higher grain participation to increase starch proportion in the material, is not absolute true, since silages well fertilized with nitrogen may have the same energy contribution with greater use of fibrous fraction.

In addition, such findings have great relevance in the context of ruminant nutrition. Corn silages with more digestible fiber can result in higher DM intake, which may reduce costs with a lower participation of concentrate in the diet and ensure ruminal health due to greater rumination through ruminal buffer, higher fat milk production and extended animal production, providing that particle size is respected (FERRARETTO \& SHAVER, 2015). Also, a lower content of ingested starch with highly digestible fiber may reduce metabolic disorders, such as ruminal acidosis, in milk and meat production systems (DE NARDI et al., 2013).

Table 2 shows a statistically significant difference $(\mathrm{P}<0.05)$ in $\mathrm{pH}$; treatments without nitrogen, with 45 and $90 \mathrm{~kg} \mathrm{~N}^{-1}$ did not differ from each other, but had statistically lower $\mathrm{pH}(\mathrm{P}<0.05)$ when compared to the treatment with $135 \mathrm{~kg} \mathrm{~N} \mathrm{ha-}$ ${ }^{1}$. An increase in GP content and the presence of organic ions from the silage generates an increase in buffer capacity, which in turn neutralizes $\mathrm{pH}$ inside the silo, and it would be considered undesirable (ROOKE \& HATFIELD, 2003).

Although a GP increase was observed, even without any increase in $\mathrm{N}_{-} \mathrm{NH}_{3}$ and in the amount of more digestible nitrogen fraction, which contributed to linear $\mathrm{pH}$ increase in this study, no harmful effect was observed on conservation, since the $\mathrm{pH}$ remained below 4.0. Moreover, the levels of $\mathrm{N}-\mathrm{NH}_{3}$ were below $10 \%$, which, according to Van SOEST (1994), suggestedoptimal storage quality of these silages, because they do not indicate proteolysis due to fermentation by clostridia.

\section{CONCLUSION}

Increase in nitrogen levels in cover fertilization of corn crops provided benefits in kinetics and chemical composition of resulting silage.

Ciência Rural, v.47, n.5, 2017. 
Table 2 - Chemical composition of corn silage grown with different cover nitrogen fertilizer treatments.

\begin{tabular}{|c|c|c|c|c|c|c|}
\hline \multirow[t]{2}{*}{ Parameter } & \multicolumn{4}{|c|}{--------------N levels of coverage $\left(\mathrm{kg} \mathrm{ha}^{-1}\right)$------------- } & \multirow[t]{2}{*}{ Average } & \multirow[t]{2}{*}{ Coefficient of Variation $(\%)$} \\
\hline & 1 & 45 & 90 & 135 & & \\
\hline \multirow[t]{2}{*}{ Dry matter, \% } & 30.15 & 27.49 & 30.60 & 30.09 & 29.58 & 5.14 \\
\hline & \multicolumn{4}{|c|}{$\%$ of MS } & & \\
\hline Organic matter & 96.27 & 96.47 & 96.75 & 96.42 & 96.48 & 0.44 \\
\hline Ethereal extract & 2.50 & 2.48 & 2.69 & 2.74 & 2.60 & 14.76 \\
\hline Neutral detergent fiber & 42.93 & 42.91 & 42.50 & 42.06 & 42.60 & 5.37 \\
\hline Acid detergent fiber & 26.16 & 28.56 & 25.59 & 25.53 & 26.46 & 7.54 \\
\hline Non-fibrous carbohydrates & 44.77 & 44.05 & 43.83 & 43.01 & 43.92 & 6.62 \\
\hline Total digestible nutrients & 67.47 & 67.31 & 67.97 & 67.92 & 67.74 & 2.16 \\
\hline \multicolumn{7}{|c|}{ 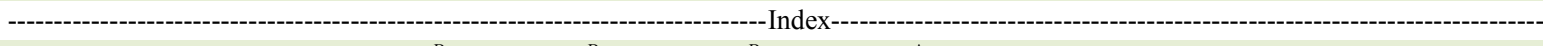 } \\
\hline $\mathrm{pH}$ & $3.31^{\mathrm{B}}$ & $3.32^{\mathrm{B}}$ & $3.35^{\mathrm{B}}$ & $3.40^{\mathrm{A}}$ & 3.35 & 0.57 \\
\hline \multicolumn{7}{|c|}{ - } \\
\hline $\mathrm{N}-\mathrm{NH}_{3}$ & 3.77 & 3.57 & 3.92 & 3.45 & 3.68 & 12.54 \\
\hline
\end{tabular}

Averages followed by different letters in the line differ $(\mathrm{P}<0.05)$ from each other by the Tukey test.

\section{REFERENCES}

ASSOCIATION OF OFFICIAL ANALYTICAL CHEMISTS (AOAC). Official methods of analysis. 16.ed. Washington, DC, 1995. 2000p.

BASSEGIO, D. et al. Short-term effects of crop rotations on soil chemical properties under no-tillage condition. Australian Journal of Crop Science, Queensland, v.9, p.49-54, 2015. Available from: $<$ http://www.cropj.com/bassegio_9_1_2015_49_54.pdf $>$. Accessed: Fev. 04, 2017. doi: 20153142241.

BOLSEN, K. K. et al. Effect of silage additives on the microbial succession and fermentation process of alfalfa and corn silages. Journal of Dairy Science, Savoy, v.75, p.3066-3083, 1992. Available from: <http://dx.doi.org/10.3168/jds.S0022-0302(92)78070-9>. Accessed: Fev. 04, 2017. doi: 10.3168/jds.S0022-0302.

CHERNEY, J. H.; CHERNEY, D. J. R. Assessing silage quality. In: BUXTON, D. R. et al. (Eds.). Silage science and technology. Madison, Wisconsin: American Society of Agronomy, 2003. p.141-198.

CNCPS. Cornell net carbohydrate and protein system. Ithaca: Cornell University, 2002. Software, version 5.0.18.

DE NARDI, R. et al. Blood parameters modification at different ruminal acidosis conditions. Agriculturae Conspectus Scientificus, Legnaro, v.78, p.259-262, 2013. Available from: $<$ http://hrcak.srce. hr/106917>. Accessed: Fev. 04, 2017. doi: 60A08-5402/13.

FERRARETTO, L. F.; SHAVER R.D.; Effects of whole-plant corn silage hybrid type on intake, digestion, ruminal fermentation, and lactation performance by dairy cows through a meta-analysis. Journal of Dairy Science, Savoy, v.98, p.2662-2675, 2015. Available from: $<$ http://dx.doi.org/10.3168/jds.2014-9045>. Accessed: Fev. 04, 2017. doi: $10.3168 /$ jds.2014-9045.

GOERING, H. K.; Van SOEST, P. J. Forage fiber analysis: apparatus reagents, procedures and some applications. Washington, D. C: [sn], 1970. (Agricultural Handbook, p.379).
HALL, M. B. Neutral detergent-soluble carbohydrates, nutritional relevance and analysis. A laboratory manual. Florida. University of Florida, 2000. 42p.

LICITRA, G. et al. Standardization of procedures for nitrogen fractionation of ruminant feeds. Animal Feed Science and Technology, London, v.57, p.347-358, 1996. Available from: $<$ http://dx.doi.org/10.1016/0377-8401(95)00837-3>. Accessed: Fev. 04, 2017. doi: 10.1016/0377-8401.

MALAVOLTA, E. et al. Nutritional status of plants: principles and applications. 2.ed. Piracicaba: Potafos, 1997. 201p.

MASOERO, F. et al. Effect of nitrogen fertilization on chemical composition and rumen fermentation of different parts of plants of three corn hybrids. Animal Feed Science and Technology, Amsterdam, v.164, p.207-216, 2011. Available from: $<$ http://dx.doi. org/10.1016/j.anifeedsci.2011.02.001>. Accessed: Fev. 04, 2017. doi: 10.1016/j.anifeedsci.2011.02.001.

NATIONALRESEARCHCOUNCIL(NRC). Nutrients requirements of beef cattle. 7.ed. Washington, DC, 1996. Total de p.248

NEUMANN, M. et al. Income and corn plant production components (Zea mays $L$.) for silage, due to nitrogen fertilization levels in coverage. Journal of Maize and Sorghum, Sete Lagoas, v.4, p.418-427, 2005. Available from: <http://10.18512/1980-6477/rbms.v4n3p418-427>. Accessed: Fev. 04, 2017. doi: 10.18512/1980-6477.

POTT, C. A et al. Green manuring as agroecological alternative for restoring soil fertility. Journal Ambience, Guarapuava, v.3, p.51-63, 2007. Available from: $<\mathrm{http} / /$ revistas.unicentro.br/index.php/ambiencia/ article/view/300/411>. Accessed: Fev. 04, 2017. doi: 300/411.

RITCHIE, S. W. et al. As the corn plant develops. Piracicaba: Potafos, 2003. 20p. (Agronomist file, n. 15 - Agricultural Information, n.103 - September / 2003)

ROOKE, J. A.; HATFIELD, R. D. Biochemistry of ensiling. Madison: Silage Science and Technology, 2003. total de p.897. 
SAS INSTITUTE. SAS / STAT user's guide: Statistics, version 6. 4.ed. North Caroline, 1993. v.2. Total de p.943.

SILVA, D. J.; QUEIROZ, A. C. Food analysis, chemical and biological methods. 3 .ed. $-4^{\text {th }}$ reprint. Viçosa: Federal University of Viçosa, 2009. Total de p.225.

SNIFFEN, C. J. et al. The net carbohydrate and protein system for Evaluating cattle diets: II Carbohydrate and protein availability. Journal Animal Science, Champaign, v.70, p.3562-3577, 1992. Available from: $<$ https://www.ncbi.nlm.nih.gov/pubmed/1459918>. Accessed: Fev. 04, 2017.

TAIZ, L.; ZEIGER, E. Plant physiology. New York: Sinauer, 2002. Total de p.690.

UENO, R. K. et al. Dynamics of nutrients in the soil in areas intended for the production of forage maize (Zea mays L.). Applied Research
\& Agrotechnology, Guarapuava, v.4, p.182-203, 2011. Available from: <http://dx.doi.org/10.5777/paet.v4i1.1427>. Accessed: Fev. 04, 2017. doi: 10.5777/paet.v4i1.1427.

Van SOEST, P. J. et al. Methods for dietary fiber, neutral detergent fiber, and nonstarch polysaccharides in relation to nutrition animal. Journal of Dairy Science, Savoy, v.74, p.3583-3597, 1991. Available from: <http://dx.doi.org/10.3168/jds.S00220302(91)78551-2>. Accessed: Fev. 04, 2017. doi: 10.3168/jds. S0022-0302.

Van SOEST, P. J. Nutritional ecology of the ruminant. 2.ed. Ithaca, New York: Cornell University, 1994. 476p.

WALTER, M. Resistant starch: quantification methodologies and biological response in rats. 2005. 96f. Dissertation (Master in Food Science and Technology) - Santa Maria: Federal University of Santa Maria, RS. 